\section{THE MENDELÉEFF-BRAUNER TRADITION IN CZECH CHEMISTRY}

\section{By Dr. GERALD DRUCE}

$\mathrm{E}$ VER since the founding of the University of Prague in 1348, the Czechs have made their contributions to the advancement of science. In the Middle Ages, Prague and other Czech towns were centres for the practice of alchemy and a number of their pharmacies date back to these times.

Even during the dark days of the seventeenth century some Czech exiles, notably J. A. Komenský (Comenius), whose pansophism influenced some of the early members of the Royal Society, and the alchemist, Daniel Stolczius, maintained a high standard of knowledge and tried to lay the foundations for a wider and more general study of science when better days returned. Meanwhile, science was at a standstill in their homeland; no lectures or training were given until the end of the eighteenth century, when a scientific revival set in, and the biological sciences attracted most attention. Indeed, it was not until the time of Bohuslav Brauner (1855-1935) that Czech chemistry attained a world-wide significance.

Curiously enough, it was Brauner who did much to popularize the Periodic System postulated by D. I. Mendeléeff in $1869^{1}$ and which might easily have received the ridicule accorded Newlands' Law of Octaves in 1863, though it was more likely to escape attention altogether on account of its appearing in an obscure Russian publication, especially as contemporary Western science was indifferent to so-called 'speculatory' articles.

The rapid verification of Mendeléeff's bold prediction of the existence of undiscovered elements, for which he left spaces in his Table, directed attention to his work, and it remained for Brauner and others to attempt to clear up the obscurities and anomalies. Thus, in order to establish his system, Mendeléeff had been obliged to alter certain accepted atomic weights (for example, that of beryllium) and to invert the order of others (for example, the pairs cobalt-nickel and tellurium-iodine). There were other problems such as that of the rare earths. To all these, Brauner gave his attention, as Mendeléeff frequently acknowledged ${ }^{2}$, and there thus developed a cultural 'neo-Slavism' as distinct from the political 'Pan-Slavism' of last century. This found expression, too, in Brauner's advocacy of the Czech transcription for Russian names ${ }^{3}$, Mendeléeff being rendered Mendølěøv, a system that is more accurate but less acceptable in Great Britain on account of the diacritical marks involved.

In 1877 , Brauner adduced evidence ${ }^{4}$ that beryllium must have an atomic weight of 9 , not 13.5 as previously supposed. This was confirmed by Nilson and Petterson, so that beryllium heads Group 2 of the Table, in accordance with Mendeléeff's arrangement. From his own investigations and by a critical study of those of Crookes and others, Brauner came to the conclusion that the rare earth elements, from lanthanum to lutecium, should be lumped together in the Periodic Table ${ }^{5}$. This work included his classical fractional separation of didymium into the three elements, neodymium, praseodymium and samarium. Brauner next devoted himself to the task of the exact determination of atomic weights, and his figures for a number of these (cerium, beryllium, praseodymium, tellurium, thorium and lanthanum) were accepted as the standard ones ${ }^{6}$. He was unable, however, to clear up the problem of the inverted order of tellurium and iodine, a question that was only solved after the discovery of atomic numbers.

In 1902, when the Periodic Classification was firmly established, Brauner again visited Mendeléeff, and his lecture at St. Petersburg (Leningrad) was one of the last meetings that Mendeléeff attended. In the following year the new Chemical Institute of the Charles University of Prague was opened, largely as a result of Brauner's efforts and through the international reputation he had by then acquired?. With better facilities at his disposal Brauner was able to educate a generation of Czech chemists before the War of 1914-18 brought liberation to his nation. A number of these continued in his researches on the rare earths, the most noteworthy being Prof. J. S. Sterrba-Böhm, who prepared and examined the lesser known compounds of cerium, scandium and germanium. Among the substances he prepared were a long list of double cerium oxalates ${ }^{8}$ and many double salts of scandium, while his later researches on germanium ${ }^{9}$, starting with a supply of argyrodite, brought the early work of Winkler up to date. His son, Dr. J. P. Sttørba-Böhm, was just beginning his career and had completed an interesting research on the sulphates, selenates and carbonates of scandium ${ }^{10}$ when the Germans marched into Prague.

Brauner's atomic weight determinations were continued at his institute by Prof. H. Kř̀pelka, who has shown equal skill and patience in estimations relating to arsenic, aluminium ${ }^{11}$ and silver ${ }^{12}$, Prof. O. Tomiček, who succeeded Prof. Stěrba-Böhm, had already specialized in improved methods of potentiometric analysis which were applied to the estimation of traces of elements as impurities and in evaluating the saline contents of thermal waters ${ }^{13}$.

Probably the most outstanding contribution to chemical science made by Brauner's successors is the polarographic work of Heyrovsky ${ }^{14}$ and his collaborators. This method, using the dropping mercury cathode, was first described in 1925, and though a steady stream of communications on the subject continued to appear, it was not until several years after that the full significance and importance of the method were appreciated. During the last few years it has found very wide application in many different directions. With the polarographic apparatus analyses can be carried out with so little as 2 c.c. of solution of $10^{-5}$ molar concentration and only requires that a known amount of the material under examination be brought into convenient solution, with perhaps the elimination of any interfering element. The automatically recorded polarogram constitutes a permanent record of the information obtained.

It was used, among other things, for the detection of Mendeléeff's dvi-manganese (rhenium) in crude manganese salts ${ }^{15}$ and may thus be said to have assisted in filling one of the gaps in the Periodic Table, allowed for by Mendeléeff in 1869. Most of these gaps have now been filled, several during the period that Czechoslovakia was able to expand its scientific and research programmes. Thus, in 1922, hafnium was discovered ${ }^{16}$ (or re-discovered), and Brauner put in a plea for the retention of Urbain's name, celtium, for this element ${ }^{17}$. Mention has been made of Czech contributions to the discovery of the congeners of manganese, now known as masurium 
and rhenium. A third congener, which would have an atomic number of 93 and would thus be the next element beyond uranium, was announced by Koblic in $1935^{18}$. It was said to be present in certain residues from the working up of pitchblende for radium at Jáchymov (St. Joachimsthal), but as spectroscopic examination failed to reveal any new body, Koblic soon withdrew his claim to the discovery of bohemium, as he called the new element. In passing, it may be mentioned that in 1934 the hundredth gram of radium was extracted at Jáchymov, though by that time the Czech source of radium and pitchblende had lost its importance since far greater supplies are available in the Belgian Congo and near the Great Bear Lake in Canada. Nevertheless, Czech chemists and radiologists made valuable studies and applications of their supplies, particularly in medicine.

Brauner's life and work were influenced not only by his contacts with Mendeléeff but also by his connexions with Great Britain. His first interest in England began when as a boy he received a chemical set known as "Tutton's Chemical Box", which Prof. Frič took back to Prague from London. Later, in the 'eighties, he studied at Manchester under Roscoe and afterwards revisited England, taking the opportunity to read some papers before the Chemical Society ${ }^{19}$. It therefore became a part of his tradition that promising students were sent abroad to widen their outlook. Thus Sterrba-Böhm went to Paris to work under Moissan and Becquerel, Heyrovský came to London to hear Ramsay, Donnan and many other contemporary great chemists, Krepelka went to the United States to work under Richards. Between 1918 and 1938 a number of Czech students went abroad to spend at least a year of their academic life under Western influence. To-day it is only abroad that they are able to continue their researches and studies, for in the "protectorate" all universities and institutes are closed. When the nation is again liberated and the universities are opened once more, there is no doubt that the Mendeléeff-Brauner tradition of Czech chemistry will again inspire the nation's chemists to achieve results for the general advancement of science and the welfare of mankind.

\footnotetext{
II March 1869, Mendeléeff circulated a memoir among members of the Russian Ohemical Society. It set out his views on the periodi city of the elements and contained his first Periodic Table. The memoir was later reprinted in the Society's Journal.

2 For example, in his "Principles of Chemistry".

a NATURE, 109, 552 (1922).

4 Chem Listy, 2, 30, 87, 129 (1877).

${ }^{5}$ J. Chem. Soc., 41, 68 (1882); Ber., 11, 872 (1878).

- J. Chem. Soc., 67, 549 (1895).

Rec. trav. chim., 44, 281 (1925).

${ }^{8}$ Collection Czech. Chem. Comm., 7, 57 and 131 (1936).

- Collection Czech. Chem. Comm., 5, 233 (1933).

${ }^{10}$ Collection Czech. Chem. Comm., 10, 8 (1938).

${ }^{21}$ Collection Czech. Chem. Comm., 2, 255 (1930); Chem. Listy, 19, 158 (1925).

23 NAture, 119, 348, 526 (1927); J. Amer. Chem. Soc., 42, 155 (1920).

${ }^{2}$ Collection Czech. Chem. Comm., 2, 1 (1980).

"Rec. trav. chim., 44, 488 (1925). Several monographs have recently appeared dealing with polarography, and there is an extensive
list of references in Chemistry and Industry, 60,778 (1941).

16 NATURE, 117, 782 (1925).

16 NATURE, 111, 79 (1923).

17 Chemistry and Industry, 42, 884 (1923).

${ }_{18}$ NATURE, 134, 55 and 282 (correction) (1935).

1. Proc. Chem. Soc., 67-72 (1898); ibid., 63-68 (1901).
}

\section{LANDSCAPE IMPRESSION AND THE EXTERNAL BASIS OF NATURAL BEAUTY}

\author{
By L. C. W. BONACINA
}

T $T$ is often said with some truth that this century I has seen a welcome change from the last towards a desire to bring scientific knowledge and $x$ sthetic appreciation of Nature more into line in human thought. Yet there were already signs of a change of outlook during the nineteenth century. That shrewd cosmopolitan thinker, Alexander von Hum. boldt, who helped to lay the foundations of so many of the geophysical and geographical sciences and saw so much of Nature in many lands, considered that it was not altogether possible to dissociate æsthetics from science in the study and contemplation of landscapes. As to Victorian England, it is in. structive in this regard to note the respective attitudes of Tyndall and Geikie, for example, in science, and of Ruskin and Wordsworth in art and poetry.

Whatever may have been John Tyndall's theological views there can be no question that the whole outlook upon Nature of this celebrated physicist was consciously and deliberately artistic, and there are passages in his "Hours of Exercise in the Alps" which almost vie in descriptive power with Ruskin himself, leaving the reader with the conviction that to this great-hearted Irishman there was much more in the mountains than was comprised in their dimensions, form, structure and composition. Similarly, the eminent Scottish geologist, Sir Archibald Geikie, displays in his "Landscape in History and other Essays", which considers the human response to different types of country in Great Britain as also in Italy and Greece, highly imaginative insight into those imponderable but powerful environmental influences so vividly reflected in literature. Conversely, though the art critic, John Ruskin, may have given vent to irritable denunciations of scientific research, no one more loudly proclaimed the importance for creative work of careful and accurate, that is, scientific observation of natural phenomena, even going so far as to declare quite unjustly to Constable and others that no landscape painter before Turner had ever really looked at the clouds. In like manner, though William Wordsworth may have passed occasional rude remarks about geologists and astronomers, there is something in his very Naturemysticism, unique among the great English poets, which is very reassuring from the wider philosophical and scientific point of view, and it is surely significant that a Wordsworthian text should have been selected as a motto for NATURE. Throughout Wordsworth we discern in the background tacit acceptance of scientific principle which makes for stability and enhances the value of much deep and passionate expression of feeling. There is a curious passage in the second book of "The Prelude" wherein the poet is thinking of the sun and moon both as cosmical bodies and as elements in the local landscape, and says of the latter, with respect to a beloved Cumbrian vale, that she hung

"Midway between the hills, as if she knew

No other region, but belonged to thee,

Yea, appertained by a peculiar right

To thee and thy grey huts, thou one dear Vale !" 